\title{
Formulation and Evaluation of Dehydrated Greens Incorporated Value Added Products
}

\author{
Sushmita Khatoniar*, Mridula Saikia Barooah and Mamoni Das \\ Department of Food Science and Nutrition, College of Community Science, Assam \\ Agricultural University, Jorhat, Assam-785013, India \\ *Corresponding author
}

\section{A B S T R A C T}

\section{Keywords}

Micronutrients,

Dehydration,

Rehydration

Article Info

Accepted:

02 May 2018

Available Online:

10 June 2018
The present investigation was aimed to increase consumption of green leafy vegetables in the daily diet thus combating the micronutrient deficiencies, especially iron and calcium. A series of laboratory experiments were carried out to study nutritional constituents of some selected green leafy vegetables and after comparing the iron and calcium content of the dehydrated green leafy vegetables, Amaranthus spinosus, Talinum triangulare and Chenopodium album were found to be higher in both iron and calcium content. So, these three green leafy vegetables were selected for incorporation in various products. These greens were mixed in three different proportions and these formulations were computed for nutritional and tested for rehydration and Formulation- 1 was judged nutritionally superior and showed good physical properties after rehydration. Hence, Formulation 1 was incorporated in preparation of various recipes at $10 \%, 15 \%$ and $20 \%$ level and these were found acceptable upto $15 \%$ level of incorporation.

\section{Introduction}

Green Leafy Vegetables (GLV) are treasure house of nutrients, specially micronutrients in particular, are available at low cost during the seasons in Assam. Owing to high moisture content, green leafy vegetables are highly perishable and are sold at throwaway prices in the peak season resulting in heavy losses to the growers due to non-availability of sufficient storage, transport and proper processing facilities at the production point (Pande et al., 2000). Augmenting utilization and avoiding wastage calls for employing suitable preservation techniques that are userfriendly and sustainable at the household level. Dehydration is one of the traditional methods of preservation, which converts the food in to light weight, easily transportable and storable product. Advantage of this method, if employed for vegetables, is that it can be easily converted in to fresh-like form by rehydrating and can be used throughout the year. It facilitates the utilization of the dried leaves in other parts of the country or world where this vegetable is unavailable in plenty. In addition to increasing variety in the menu, reducing wastage, labour and storage space, dehydrated vegetables are simple to use and have longer shelf life than fresh vegetables (Chauhan and Sharma, 1993). In order to place the GLVs in to the routine diets and to 
break monotony of the meals, it becomes essential to convert the traditional products in to attractive, value added acceptable products. The present investigation is an attempt to dehydrate the commonly consumed GLVs and to extend the utility of dehydrated vegetables in traditional recipes for micronutrient security.

\section{Materials and Methods}

On the basis of the preliminary screening of 20 locally available green leafy vegetables for micronutrients, three greens were selected on the basis of higher iron and calcium content. The raw material required for the study were procured from local market, sorted with tender stem along with healthy leaves and were washed under tap water then with distilled water. The procedure was repeated till the vegetables are devoid of dirt and soil. The GLVs were dried by cabinet dryer at $60^{\circ} \mathrm{C}$. Drying was continued till the GLVs became crisp. The dehydrated GLVs were packed in polyethylene and HDPE pouches and stored for evaluation of shelf life. Moisture, ash, crude fibre, calcium and potassium were estimated following AOAC standard methods (2000, 1984). Iron content was determined using Wong's method and phosphorous was estimated by method described by Fiske and Row (Ranganna, 1986). Vitamin C content was determined by volumetric method (Freed, 1966). The rehydration ratio of dehydrated leaves was estimated using the method suggested by Patil et al., (1978). The microbial analysis of the stored products was done at the end of storage period of 60 days in terms of aerobic plate count (AOAC, 1995).

\section{Results and Discussion}

\section{Formulation of greens mixture}

After comparing the iron and calcium content of the dehydrated green leafy vegetables,
Amaranthus spinosus, Talinum triangulare and Chenopodium album were found to be higher in both iron and calcium content as compared to other selected green leafy vegetables. These greens also contains a good amount of phosphorous and potassium. The retention of ascorbic acid content of these green leafy vegetables is also quite satisfactory (Fig. 1).

These dried greens also show good rehydration when hydrated. Thus observing all the aspects, three green leafy vegetables Amaranthus spinosus, Talinum triangulare and Chenopodium album were selected for further purposes.

The three dehydrated green leafy vegetables Amaranthus spinosus, Talinum triangulare and Chenopodium album were mixed in various proportions and acceptability tests were carried out. The greens mixture was tried to formulate in such a way so that maximum benefit of nutrients with special reference to calcium and iron can be obtained within the accepted level. The three greens were mixed in following ratios -

Formulation 1: 60g (A. spinosus): $20 \mathrm{~g}$ (T. triangulare): $20 \mathrm{~g}$ (C. album)

Formulation 2: $50 \mathrm{~g}$ (A. spinosus): $30 \mathrm{~g}$ ( $T$. triangulare): $20 \mathrm{~g}$ (C. album)

Formulation 3: 40g (A. spinosus): 30g ( $T$. triangulare): $30 \mathrm{~g}$ (C. album)

Nutritional value of these formulations were computed and tested for physical parameters after rehydration.

The nutritive value of the formulations and rehydration ratio are given in Table 1 and Figure 2 and it was found that Formulation 1 was nutritionally superior as well as having good physical properties after rehydration. 


\section{Development of} incorporated recipes

Dehydrated greens can be utilized in multiple ways by incorporating into existing products and formulation of nutrient rich value added products. It is essential to look for sustainable, culturally acceptable, cost effective strategy by which consumption of greens can be increased and thereby combating micronutrient deficiencies. The selection of recipes was done by keeping in mind the consumption pattern and changes in life-style of modern households. The recipes were selected with the purpose to combat micronutrient deficiencies as well as to increase consumption of green leafy vegetables. In addition, it is also aimed to break monotony, provide satisfaction and add variety to the diet. The selected formulation of the greens mixture $(60 \mathrm{~g}$ A. spinosus, $20 \mathrm{~g} T$. triangulare and $20 \mathrm{~g}$ C. album per $100 \mathrm{~g}$ ) was used in preparation of various recipes. Table 2 enlists the developed products by incorporating Formulation 1 greens mixture.

Formulated greens mixture (Formulation 1) was incorporated into the above products with an aim of facilitating the consumption of green leafy vegetables as well as to help combat micronutrient deficiency. The selected recipes were consumed by almost all of the age groups of Indian population and can be prepared with fewer ingredients and in less time. Though children and adolescents are at risk for micronutrient deficiency, they mostly prefer snacks and fast food items. Therefore, by enriching the snack items such as pakoda with dehydrated green leafy vegetables, micronutrient content of the diet can be ensured. Greens incorporated roti can be provided as a breakfast item, tiffin item as well as can be consumed as meal. The biscuits, pakodaand nimkee are the products which are commonly consumed as snack items between the meals. nimkee (baked and fried) and salty biscuit can also be prepared for commercial purpose as these products have good market demand. Hence, fortification of these common foods with dehydrated green leafy vegetables can be a way to incorporate micronutrients in the diet without much effort. This food based strategy is much safer than medicated supplementation (Table 3).

In the present study, the greens incorporated products were found with high amount of micronutrients specially calcium and iron. Highest calcium content was found in greens incorporated pakoda $(391.83 \mathrm{mg} / 100 \mathrm{~g})$ followed byroti $(382.60 \mathrm{mg} / 100 \mathrm{~g})$, baked nimkee $(243.10 \mathrm{mg} / 100 \mathrm{~g})$, salty biscuit $(232.50 \mathrm{mg} / 100 \mathrm{~g})$ and fried nimkee $(225.80$ $\mathrm{mg} / 100 \mathrm{~g})$. The iron content of the products was in the range of 7.67-12.56 mg/100g. Per $10 \mathrm{~g}$ of Formulation 1 greens mixture provides $221.02 \mathrm{mg}$ calcium and $6.28 \mathrm{mg}$ iron, so by incorporating greens mixture in various proportion to common recipes, the calcium and iron content can be increased.

Verma and Jain (2012) assessed the nutritional quality of mathri fortified with fresh and dehydrated vegetables (spinach $1.50 \mathrm{~g}$, mint $1.50 \mathrm{~g}$, carrot $1 \mathrm{~g}$ and lotus stem $6 \mathrm{~g}$ ) in $7 \%$ incorporation in mathri. Iron content was high in dried vegetables mathri was $5.37 \mathrm{mg}$ in comparison to mathri prepared with fresh greens $(1.30 \mathrm{mg})$. The ash content was $2.10 \%$ and $1.40 \%$ for dried and fresh respectively. In the present study, the iron content of fried and baked nimkee was increased to 7.67 and 8.10 $\mathrm{mg} / 100 \mathrm{~g}$ at $15 \%$ level of incorporation. Wani et al., (2011) estimated the chemical constituents (moisture, protein, fat, ash and fibre) of noodles by adding cauliflower leaf powder to the noodle formulation at the level of $0,10,15$, and $20 \%$ flour weight basis and indicated that noodles with cauliflower leaf powder for all addition levels contained more protein, fibre and ash in comparison to control sample. 
Table.1 Nutrient composition of the formulated greens mixtures (per 100g)

\begin{tabular}{|c|c|c|c|c|c|c|c|c|}
\hline $\begin{array}{c}\text { Green leafy } \\
\text { vegetables }\end{array}$ & $\begin{array}{c}\text { Moisture } \\
(\mathbf{g})\end{array}$ & $\begin{array}{c}\text { Ash } \\
(\mathbf{g})\end{array}$ & $\begin{array}{c}\text { Crude } \\
\text { fibre } \\
(\mathbf{g})\end{array}$ & $\begin{array}{c}\text { Calcium } \\
(\mathbf{m g})\end{array}$ & $\begin{array}{c}\text { Iron } \\
(\mathbf{m g})\end{array}$ & $\begin{array}{c}\text { Phosphorous } \\
(\mathbf{m g})\end{array}$ & $\begin{array}{c}\text { Potassium } \\
(\mathbf{m g})\end{array}$ & $\begin{array}{c}\text { Vit. } \\
\text { C } \\
(\mathbf{m g})\end{array}$ \\
\hline Formulation 1 & 4.63 & 14.45 & 9.85 & 2212.05 & 62.78 & 310.20 & 2289.10 & 10.34 \\
\hline Formulation 2 & 4.68 & 13.78 & 8.32 & 2050.70 & 56.92 & 345.20 & 2752.40 & 10.70 \\
\hline Formulation 3 & 4.67 & 13.25 & 8.11 & 1872.91 & 50.77 & 352.30 & 2659.50 & 11.54 \\
\hline
\end{tabular}

Table.2 Development of greens incorporated recipes for calcium and iron security

\begin{tabular}{|l|l|c|}
\hline \multicolumn{1}{|c|}{$\begin{array}{c}\text { Name of the } \\
\text { products }\end{array}$} & \multicolumn{1}{|c}{\begin{tabular}{c}
\multicolumn{1}{|c}{ Ingredients used } \\
Roti
\end{tabular}} & $\begin{array}{c}\text { \% } \begin{array}{c}\text { Level of incorporation } \\
\text { of greens mixture }\end{array} \\
\text { for kneading }\end{array}$ \\
\hline Pakoda & $\begin{array}{l}\text { Bengal gram flour, onion, green chilli, ginger, } \\
\text { baking soda, salt, oil (for frying) }\end{array}$ & 10,15 and 20 \\
\hline Fried nimkee & $\begin{array}{l}\text { Refined wheat flour, dalda, sugar, salt, black } \\
\text { cumin, oil (for frying) }\end{array}$ & 10,15 and 20 \\
\hline Baked nimkee & $\begin{array}{l}\text { Refined wheat flour, dalda, sugar, salt, black } \\
\text { cumin }\end{array}$ & 10,15 and 20 \\
\hline Salty biscuit & $\begin{array}{l}\text { Refined wheat flour, dalda, sugar, salt, egg, } \\
\text { baking powder, black cumin }\end{array}$ & 10,15 and 20 \\
\hline
\end{tabular}

Table.3 Nutrient composition of greens incorporated products (per 100g)

\begin{tabular}{|l|c|c|c|c|c|c|c|c|}
\hline Products & $\begin{array}{c}\text { Moisture } \\
(\mathbf{g})\end{array}$ & $\begin{array}{c}\text { Ash } \\
(\mathbf{g})\end{array}$ & $\begin{array}{c}\text { Crude } \\
\text { fiber } \\
(\mathbf{g})\end{array}$ & $\begin{array}{c}\text { Calcium } \\
(\mathbf{m g})\end{array}$ & $\begin{array}{c}\text { Iron } \\
(\mathbf{m g})\end{array}$ & $\begin{array}{c}\text { Phosphorous } \\
(\mathbf{m g})\end{array}$ & $\begin{array}{c}\text { Potassium } \\
(\mathbf{m g})\end{array}$ & $\begin{array}{c}\text { Vit } \\
\text { C } \\
(\mathbf{m g})\end{array}$ \\
\hline Roti & 23.48 & 4.12 & 3.89 & 382.60 & 12.10 & 278.34 & 374.83 & 1.12 \\
\hline Pakoda & 15.53 & 2.04 & 2.21 & 391.83 & 12.56 & 262.13 & 353.56 & 0.93 \\
\hline $\begin{array}{l}\text { Fried } \\
\text { nimkee }\end{array}$ & 4.03 & 2.21 & 1.52 & 225.80 & 7.67 & 103.60 & 211.40 & 0.73 \\
\hline $\begin{array}{l}\text { Baked } \\
\text { nimkee }\end{array}$ & 3.54 & 2.42 & 1.73 & 243.10 & 8.10 & 112.40 & 236.10 & 0.78 \\
\hline $\begin{array}{l}\text { Salty } \\
\text { biscuit }\end{array}$ & 3.87 & 1.65 & 1.02 & 232.50 & 7.76 & 106.70 & 228.90 & 0.67 \\
\hline
\end{tabular}


Table.4 Effect of packaging material on moisture content

\begin{tabular}{|c|c|c|c|c|}
\hline \multirow[t]{2}{*}{ Product } & \multirow[t]{2}{*}{ Storage days } & \multicolumn{3}{|c|}{ Moisture content (g/100g) } \\
\hline & & $\begin{array}{l}\text { Plastic bottle } \\
\text { (TARSON) }\end{array}$ & $\begin{array}{l}\text { HDPE (200 } \\
\text { gauge) }\end{array}$ & $\begin{array}{l}\text { PP (100 } \\
\text { gauge) }\end{array}$ \\
\hline \multirow{3}{*}{$\begin{array}{l}\text { Greens mixture } \\
\text { (reduced to pieces) }\end{array}$} & 0 & $3.76 \pm 0.24$ & $3.76 \pm 0.18$ & $3.76 \pm 0.28$ \\
\hline & 30 & $3.91 \pm 0.17$ & $3.84 \pm 0.26$ & $3.97 \pm 0.24$ \\
\hline & 60 & $4.12 \pm 0.18$ & $3.98 \pm 0.17$ & $4.18 \pm 0.22$ \\
\hline \multirow{3}{*}{$\begin{array}{l}\text { Greens mixture } \\
\text { (powder) }\end{array}$} & 0 & $3.70 \pm 0.26$ & $3.70 \pm 0.19$ & $3.70 \pm 0.26$ \\
\hline & 30 & $3.88 \pm 0.19$ & $3.81 \pm 0.24$ & $3.94 \pm 0.14$ \\
\hline & 60 & $4.03 \pm 0.17$ & $3.90 \pm 0.26$ & $4.11 \pm 0.18$ \\
\hline \multirow[t]{3}{*}{ Nimkee (fried) } & 0 & $4.14 \pm 0.18$ & $4.14 \pm 0.21$ & $4.14 \pm 0.19$ \\
\hline & 30 & $4.28 \pm 0.24$ & $4.22 \pm 0.26$ & $4.37 \pm 0.28$ \\
\hline & 60 & $4.52 \pm 0.17$ & $4.41 \pm 0.18$ & $4.63 \pm 0.21$ \\
\hline \multirow[t]{3}{*}{ Nimke (baked) } & 0 & $3.95 \pm 0.26$ & $3.95 \pm 0.28$ & $3.95 \pm 0.22$ \\
\hline & 30 & $4.21 \pm 0.21$ & $4.10 \pm 0.24$ & $4.26 \pm 0.18$ \\
\hline & 60 & $4.32 \pm 0.19$ & $4.23 \pm 0.22$ & $4.43 \pm 0.14$ \\
\hline \multirow[t]{3}{*}{ Salty Biscuit } & 0 & $4.35 \pm 0.24$ & $4.35 \pm 0.17$ & $4.35 \pm 0.21$ \\
\hline & 30 & $4.49 \pm 0.18$ & $4.42 \pm 0.19$ & $4.58 \pm 0.17$ \\
\hline & $60^{\circ}$ & $4.65 \pm 0.28$ & $4.58 \pm 0.26$ & $4.86 \pm 0.24$ \\
\hline
\end{tabular}

Mean \pm Standard deviation

Table.5 Effect of packaging material on rehydration ratio of dehydrated greens mixture
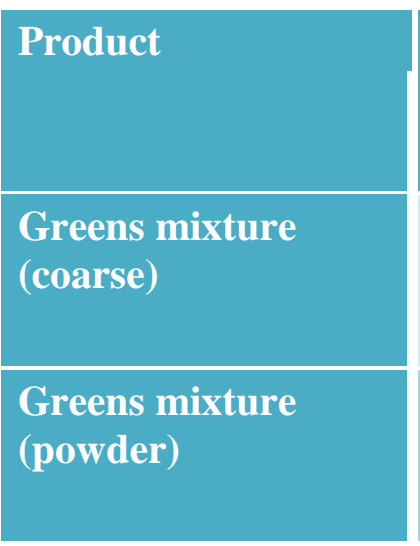

Mean \pm Standard deviation

\begin{tabular}{|c|c|c|c|}
\hline \multirow{2}{*}{ Storage days } & \multicolumn{3}{|c|}{ Rehydration ratio } \\
\cline { 2 - 4 } & $\begin{array}{c}\text { Plastic bottle } \\
\text { (TARSON) }\end{array}$ & $\begin{array}{c}\text { HDPE (200 } \\
\text { gauge) }\end{array}$ & $\begin{array}{c}\text { PP (100 } \\
\text { gauge) }\end{array}$ \\
\hline 0 & $5.70 \pm 0.26$ & $5.70 \pm 0.24$ & $5.70 \pm 0.19$ \\
30 & $5.41 \pm 0.21$ & $5.54 \pm 0.14$ & $5.37 \pm 0.22$ \\
60 & $5.12 \pm 0.19$ & $5.36 \pm 0.28$ & $5.08 \pm 0.26$ \\
\hline 0 & $5.78 \pm 0.24$ & $5.78 \pm 0.17$ & $5.78 \pm 0.28$ \\
\hline 0 & $5.48 \pm 0.22$ & $5.57 \pm 0.26$ & $5.44 \pm 0.24$ \\
60 & $5.17 \pm 0.28$ & $5.40 \pm 0.19$ & $5.10 \pm 0.21$ \\
\hline
\end{tabular}


Fig.1 Formulation of dehydrated greens mixture

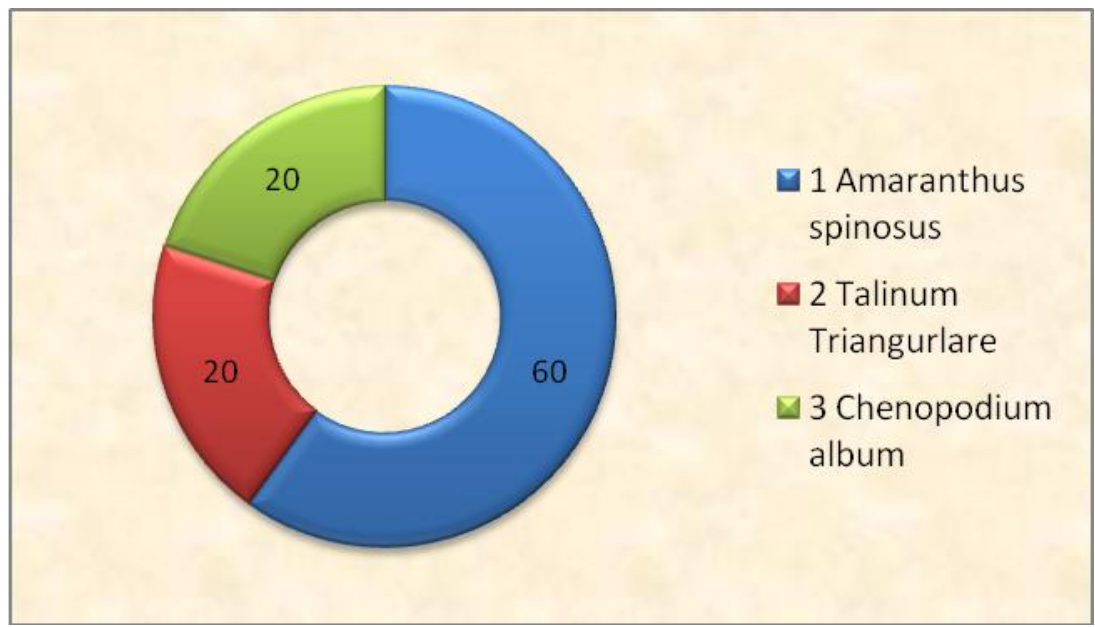

Formulation.1

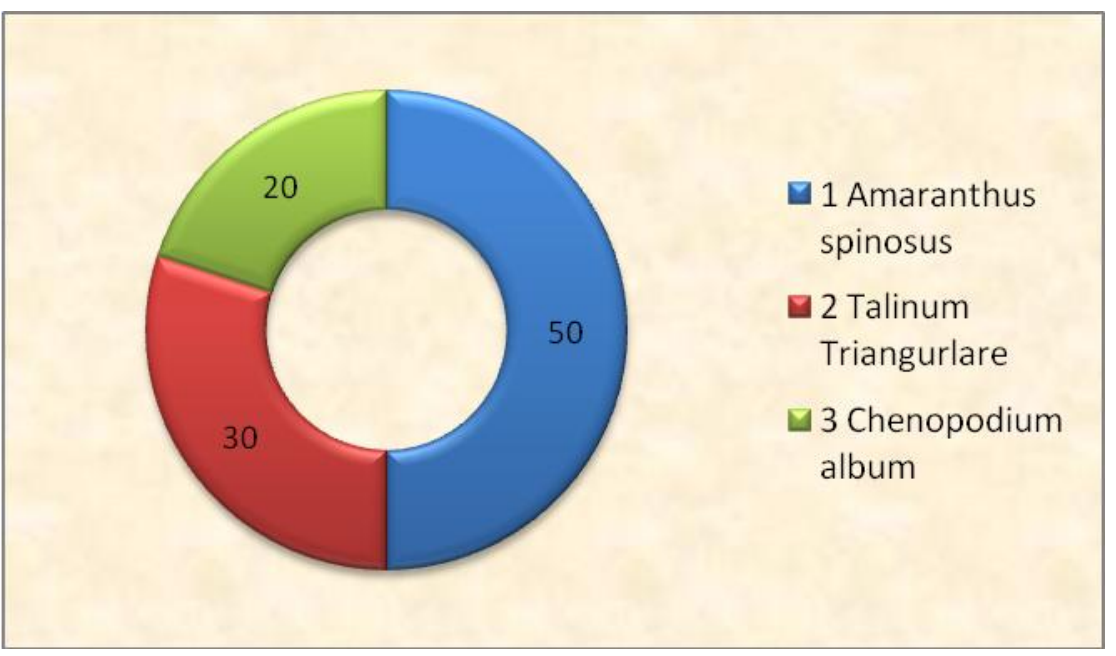

Formulation.2

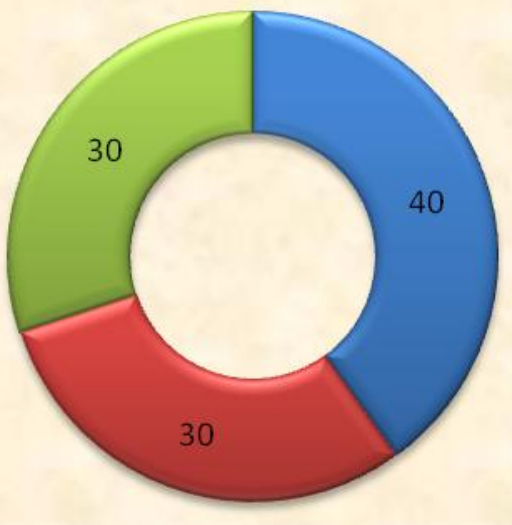

1 Amaranthus spinosus

๑2 Talinum Triangurlare

$₫ 3$ Chenopodium album

Formulation.3 
Fig.2 Rehydration ratio of the developed formulations

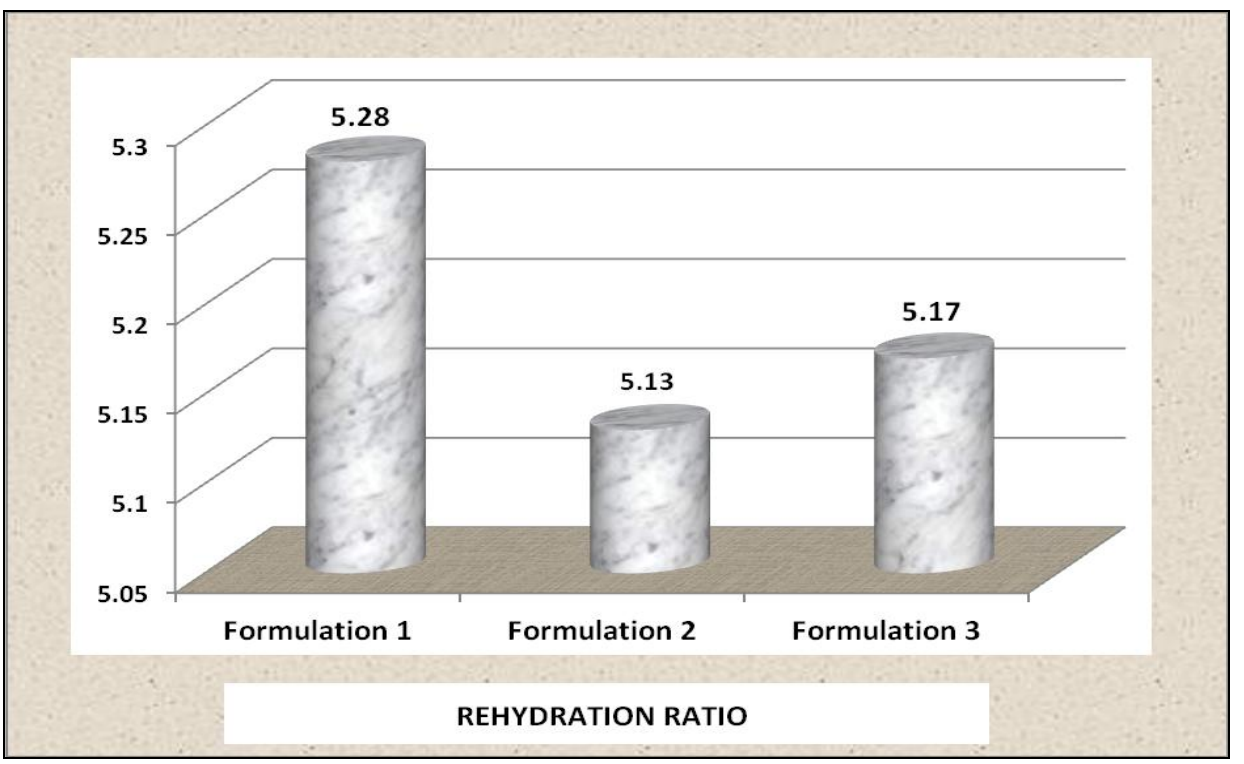

Fig.3 Aerobic plate count of dehydrated greens mixture and selected incorporated products

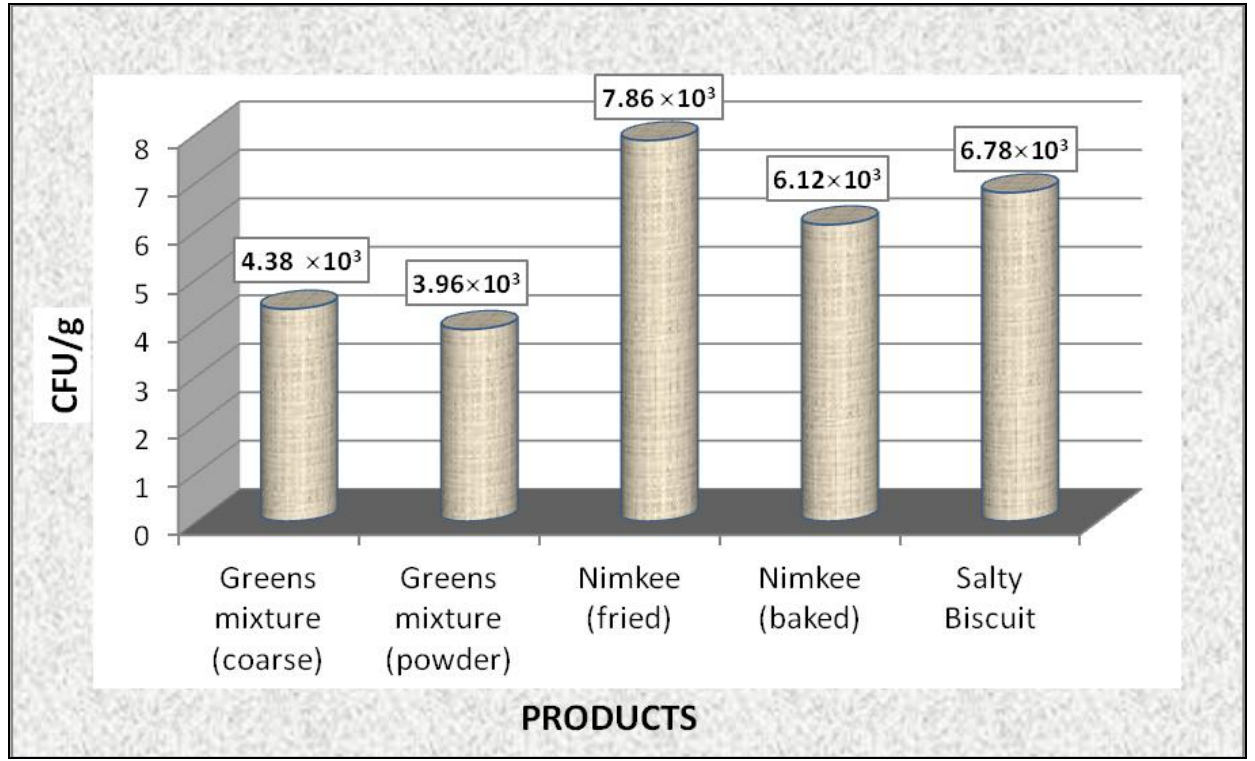

\section{Storage study of the developed products}

The formulated greens mixture and the developed products which can be stored for longer period, such as nimkee (baked and fried) and salty biscuit were studied for shelf life by evaluating moisture content and rehydration ratio of dehydrated greens in 30 days and 60 days of storage. The microbial analysis was done at the end of storage period of 60 days.

As evident from Table 4, the moisture content gradually increased on storage. Maximum increment of moisture was seen in PP pouches whereas HDPE pouch showed less increment. This may be due to structural difference, composition and thickness of the two 
materials. The water vapour transition rate of the two packaging material differs which resulted in variation of moisture content of the studied product.

From the Table 5, it is observed that rehydration ratio of dehydrated green leafy vegetables decreased on storage and was also observed variation in different packaging materials. Highest rehydration ratio was observed in HDPE packaged dehydrated greens and lowest in PP pouch packaged greens. As more moisture permeates through PP pouches than HDPE pouches, this leads to decrease in rehydration ratio of the dehydrated greens. Singh and Sagar (2010) and Seevaratnam et al., (2012) reported similar results where HDPE packaged greens showed more rehydration ratio as compared to PP packaged leaves. Hence, HDPE was found to be more suitable for storage.

In the present study, the dehydrated greens mixture and selected greens incorporated products packaged in HDPE pouches were analyzed for aerobic plate count at the end of the storage period of 60 days.

As evident from Figure 3, the total colony forming unit (CFU) was highest in fried nimkee and lowest in powdered greens mixture. Total CFU was less in baked nimkee as compared to fried nimkee. This may be due to high moisture content of fried nimkee than baked nimkee. The microbial load of the dehydrated greens was low due to low moisture content which hampers the growth of microorganism. In case of baked products, the temperature employed during cooking is more $\left(150-175^{\circ} \mathrm{C}\right)$ which may decrease the initial microbial load of the product.

Thus from the microbial analysis, it was observed that these products can be stored upto 60 days without any marked growth of microorganisms.
Green leafy vegetables are the treasure trove of micronutrients and judicious combination of green leafy vegetables might serve as richer source of specific micronutrients. Dehydrated green leafy vegetables will serve as an instant food ingredient to be used without laborious pre-processing. Dehydration also increases shelf-life of the greens. Dehydrated green leafy vegetables can be efficiently utilized for processing of value added products. Consumption of dehydrated green leafy vegetables incorporated products in daily diet will ensure micronutrient security.

\section{References}

A.O.A.C. (1984). Official methods of Analysis of the Association of Official Analysis Chemists, Washington D.C., pp. 191-213.

A.O.A.C. (1995). Official methods of Analysis of the Association of Official Analysis Chemists, Washington D.C. $16^{\text {th }}$ edition.

A.O.A.C. (2000). Official Methods of Analysis. Association of Official Analytical Chemists (17 $7^{\text {th }}$ ed.) Washington, D.C.

Chauhan, S.K. and Sharma, C.R. (1993). Development of instant dehydrated saag. Beverage and Food World 20(4): 25-26.

Freed, M., 1966. Method of vitamin assay. Interscience Publication Inc., New York.

Pande, V.K., Sonune, A.V. and Philip, S.K. (2000). Solar drying of coriander and methi. J. Fd. Sci. Technol. 37(2): 110113.

Patil, V.R., Kulkarni, D.N., Kulkarni, K. and Ingle, U.M. (1978). Effect of blanching factors on quality and durability of sundried and dehydrated fenugreek (methi). Indian Food Packer 32(1): 4349. 
Ranganna, S. (1986). In Handbook of analysis and quality control for fruit and vegetable products. $2^{\text {nd }}$ Ed., Tata McGraw-Hill, New Delhi, India.

Seevaratnam, V., Banumathi, P., Premalatha, M.R., Sundaram, S.P. and Arumugam, T. (2012). Effect of Packaging Materials on Retention of Quality
Characteristics of Selected Dehydrated Green Leafy Vegetables during Storage. World J. Dairy Fd. Sci. 7(2): 190-194.

Singh, U. and Sagar, V.R. (2010). Quality characteristics of dehydrated leafy vegetables influenced by packaging materials and storage temperature. $J$. Sci. Indust. Res. 69: 785-789.

\section{How to cite this article:}

Sushmita Khatoniar, Mridula Saikia Barooah and Mamoni Das. 2018. Formulation and Evaluation of Dehydrated Greens Incorporated Value Added Products. Int.J.Curr.Microbiol.App.Sci. 7(06): 94-102. doi: https://doi.org/10.20546/ijcmas.2018.706.013 